\title{
Amycolatopsis thermoflava sp. nov., a novel soil actinomycete from Hainan Island, China
}

\author{
Jongsik Chun, ${ }^{1,4}$ Seung Bum Kim, ${ }^{2}$ Youn Kyung Oh, ${ }^{3}$ Chi-Nam Seong, ${ }^{3}$ \\ Dong-Hun Lee, ${ }^{4,5}$ Kyung Sook Bae, ${ }^{4}$ Kye-Joon Lee, ${ }^{1}$ Sa-Ouk Kang, ${ }^{1}$ \\ Yung Chil Hah ${ }^{1}$ and Michael Goodfellow ${ }^{2}$
}

Author for correspondence: Michael Goodfellow. Tel: +44 191222 7706. Fax: +441912225228. e-mail:m.goodfellow@ncl.ac.uk

\footnotetext{
1 Department of Microbiology, College of Natural Sciences and Research Center for Molecular Microbiology, Seoul National University, Seoul 151-742, Republic of Korea

2 Department of Agricultural and Environmental Science, University of Newcastle, Newcastle upon Tyne NE1 7RU, UK

3 Department of Biology, College of Natural Sciences, Sunchon National University, Sunchon 540742, Republic of Korea

4 Korea Collection for Type Cultures, Korea Research Institute of Bioscience and Biotechnology, PO Box 115 , Yusong, Taejon 305600 , Republic of Korea

${ }^{5}$ Division of Life Sciences, Chungbuk National University, Gaeshin-dong, Cheongju, Chungbuk 361 763 , Republic of Korea
}

\begin{abstract}
A soil isolate, which had been assigned to the genus Nocardia, was shown to have properties consistent with its classification in the genus Amycolatopsis. An almost complete nucleotide sequence of the 165 rDNA of the strain was determined following cloning and sequencing of the amplified gene. The sequence was aligned with those available for members of the family Pseudonocardiaceae and related taxa and phylogenetic trees were inferred using three tree-making algorithms. The organism consistently formed a distinct monophyletic clade with the type strain of Amycolatopsis methanolica, but DNA-DNA relatedness data showed that the two strains belonged to distinct genomic species. The organism was also distinguished from the type strains of all validly described species of Amycolatopsis using a battery of phenotypic properties. The genotypic and phenotypic data show that the strain merits recognition as a new species of the genus Amycolatopsis. The name proposed for the new species is Amycolatopsis thermoflava sp. nov. The type strain is IFO $14333^{\top}$.
\end{abstract}

Keywords: Amycolatopsis thermoflava sp. nov., polyphasic taxonomy, $16 \mathrm{~S}$ rDNA sequencing

\section{INTRODUCTION}

The genus Amycolatopsis was proposed by Lechevalier et al. (1986) for mycolateless actinomycetes previously classified in the genus Nocardia. Members of the genus are aerobic, Gram-positive, non-acid-fast, non-motile organisms which form a branched substrate mycelium that fragments into squarish elements. When formed, aerial hyphae may be sterile or differentiate into long chains of smooth-walled, squarish to ellipsoidal sporelike structures. The organism contains meso-diaminopimelic acid $\left(\mathrm{A}_{2} \mathrm{pm}\right)$, arabinose and galactose (wall

\footnotetext{
The GenBank accession numbers for 16S rDNA sequences of Amycolatopsis alba DSM 44262 ${ }^{\top}$, Amycolatopsis coloradensis NRRL 3218' ${ }^{\top}$, Amycolatopsis sulphurea DSM 46092 ${ }^{\top}$ and Amycolatopsis thermoflava $\mathrm{N}^{1165^{\top}}$ are AF051340, AF051341, AF051343 and AF052390, respectively.
}

chemotype IV sensu Lechevalier \& Lechevalier, 1970), is rich in fatty acids of the iso- and anteiso-branched series, contains di-, tetra- and hexahydrogenated menaquinones with nine isoprene units as the predominant isoprenologue and phosphatidylethanolamine and phosphatidylglycerol as major polar lipids with diphosphatidylglycerol, phosphatidylinositol and phosphatidylinositol mannosides variably present. The $\mathrm{G}+\mathrm{C}$ content of the DNA is in the range $66-73 \mathrm{~mol} \%$. The genus encompasses ten validly described species and forms a phyletic line within the evolutionary radiation occupied by the family Pseudonocardiaceae (Embley et al., 1988; Warwick et al., 1994; Kim \& Goodfellow, 1999).

The present investigation was designed to establish the taxonomic position of a soil isolate, designated $\mathrm{N} 1165^{\mathrm{T}}$, which had been classified as a new species of 


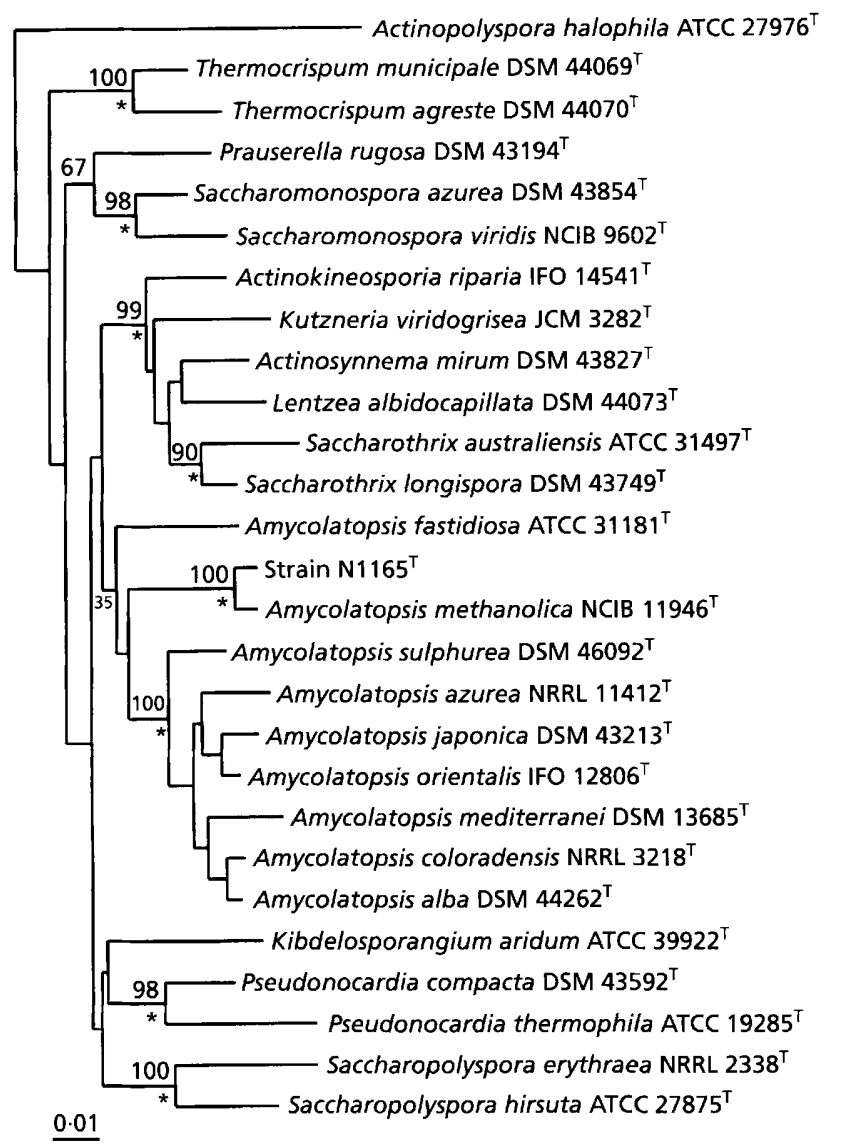

Fig. 1. Unrooted neighbour-joining tree based on nearly complete 16S rDNA sequences showing relationships between strain $\mathrm{N} 1165^{r}$ and representatives of the family Pseudonocardiaceae and related taxa. The asterisks indicate the branches that were also recovered using the Fitch-Margoliash and maximum-parsimony methods. The numbers at the nodes indicate the levels of bootstrap support based on neighbourjoining analyses of 1000 resampled data sets. Scale bar, 0.01 nucleotide substitutions per nucleotide position.

Nocardia, namely 'Nocardia thermoflava', on the basis of a few biochemical, morphological and physiological properties (Lu \& Yan, 1983). This name was neither included in the Approved Lists of Bacterial Names (Skerman et al., 1980) nor recognized in the current edition of Bergey's Manual of Systematic Bacteriology (Williams et al., 1989). Genotypic and phenotypic data show that 'Nocardia thermoflava' strain N1165 should be recognized as a new species of Amycolatopsis for which the name Amycolatopsis thermoflava sp. nov. is proposed.

\section{METHODS}

Test strains and culture conditions. 'Nocardia thermoflava' strain $\mathrm{N} 1165^{\mathrm{T}}$, which was received from the Institute of Fermentation in Kyoto (IFO $14333^{\mathrm{T}}$ ), was isolated from a heat-treated soil sample collected in Hainan Island, China by Lu \& Yan (1983). Strain N1165 ${ }^{\mathrm{T}}$, Amycolatopsis alba DSM 44262 ${ }^{\mathrm{T}}$, Amycolatopsis azurea NRRL $11412^{\mathrm{T}}$,
Amycolatopsis coloradensis NRRL $3218^{\mathrm{T}}$, Amycolatopsis fastidiosa NRRL B-16697 ${ }^{\mathrm{T}}$ (=ATCC 31181 ${ }^{\mathrm{T}}$ ), Amycolatopsis japonica DSM 44213 ${ }^{\mathrm{T}}$, Amycolatopsis mediterranei ATCC $13685^{\mathrm{T}}$, Amycolatopsis methanolica IFO $15065^{\mathrm{T}}$ (= NCIB 11946 $)$, Amycolatopsis orientalis NRRL $2450^{\mathrm{T}}$ (= IFO $12806^{\mathrm{T}}$ ) and Amycolatopsis sulphurea DSM $46092^{\mathrm{T}}$ were maintained on glucose-yeast extract agar (GYEA; Gordon \& Mihm, 1962) at $4{ }^{\circ} \mathrm{C}$ and as suspensions of mycelial fragments and spores in glycerol $(20 \%, \mathrm{v} / \mathrm{v})$ at $-20^{\circ} \mathrm{C}$. Biomass for the chemotaxonomic and molecular systematic studies was prepared by growing strains in shake flasks of modified Sauton's broth (Mordarska et al., 1972) for $10 \mathrm{~d}$ at $30^{\circ} \mathrm{C}$. Cultures were checked for purity, harvested by centrifugation, washed with distilled water and freeze-dried.

Morphology. The morphological properties of strain N1165 were examined by light and scanning electron microscopy as described previously (Williams et al., 1983).

Phenotypic characterization. The cultural and staining properties of the test strains were determined by using standard procedures after growth on GYEA plates at $37^{\circ} \mathrm{C}$ for $7 \mathrm{~d}$. After incubation, colonies were examined both by eye and microscopically. Unless otherwise stated, the remaining tests were read after $21 \mathrm{~d}$ at $30^{\circ} \mathrm{C}$. The degradation tests were carried out using GYEA as the basal medium and the results were read after $28 \mathrm{~d}$ following the procedures of Gordon et al. (1974). The growth and enzyme tests were performed using the media and methods employed by Goodfellow et al. (1997). Acid production from sugars was determined according to Gordon et al. (1974).

Chemotaxonomy. Analyses for diaminopimelic acid and major sugars were carried out using the procedures described by Staneck \& Roberts (1974) and Lechevalier \& Lechevalier (1970), respectively. Menaquinones were extracted from dried biomass (about $50 \mathrm{mg}$ ) using the small-scale method of Minnikin et al. (1984) and purified preparations were examined by electron-impact mass spectrometry, as described previously (Chun et al., 1997). Fatty acid methyl esters were prepared and analysed using the MIDI system (Sasser, 1980). The presence of mycolic acids was checked by the acid methanolysis method according to Minnikin et al. (1980).

Determination of DNA base composition. DNA was prepared according to Chun \& Goodfellow (1995). The G+C contents of the resultant preparations were determined using the thermal denaturation $\left(T_{\mathrm{m}}\right)$ method (Mandel \& Marmur, 1968).

16S rDNA sequencing. Chromosomal DNA was isolated from strain $\mathrm{N} 1165^{\mathrm{T}}$ and from the type strains of $A$. alba, $A$. coloradensis and $A$. sulphurea, according to Chun \& Goodfellow (1995). PCR, cloning and sequencing of the resultant $16 \mathrm{~S}$ rDNA preparations was carried out using the Taq DyeDeoxy Terminator Cycle Sequencing kit (Applied Biosystems) and an Applied Biosystems 373 DNA sequencer, as described elsewhere (Chun \& Goodfellow, 1995). The resultant 16S rDNA sequences were aligned manually against corresponding sequences of representative members of the family Pseudonocardiaceae and related taxa retrieved from the GenBank database.

Unrooted evolutionary trees were inferred by using three treeing algorithms, namely the Fitch-Margoliash (Fitch \& Margoliash, 1967), maximum-parsimony (Fitch, 1972) and neighbour-joining (Saitou \& Nei, 1987) methods. The distance model of Jukes \& Cantor (1969) was used to generate an evolutionary distance matrix. The topologies of 
Table 1. Characters separating species of the genus Amycolatopsis

+ , Positive or present; w, weak positive; - , negative or absent. Strains: 1, A. thermoflava

N1 $165^{\mathrm{T}} ; 2$, A. alba DSM 44262 $; 3$, A. azurea NRRL $11412^{\mathrm{T}} ; 4$, A. coloradensis NRRL $3218^{\mathrm{T}}$;

5, A. fastidiosa NRRL B-16697 $; 6, A$. japonica DSM 44213 ${ }^{\mathrm{T}} ; 7, A$. mediterranei ATCC $13685^{\mathrm{T}}$;

$8, A$. methanolica IFO $15065^{\mathrm{T}} ; 9, A$. orientalis NRRL $2450^{\mathrm{T}} ; 10, A$. sulphurea DSM $46092^{\mathrm{T}}$.

\begin{tabular}{|c|c|c|c|c|c|c|c|c|c|c|}
\hline Character & 1 & 2 & 3 & 4 & 5 & 6 & 7 & 8 & 9 & 10 \\
\hline Presence of aerial mycelium & + & + & + & + & + & + & + & + & + & + \\
\hline \multicolumn{11}{|l|}{ Colour of aerial mycelium: } \\
\hline Blue & - & - & + & - & - & - & - & - & - & - \\
\hline Purple & - & - & - & - & + & - & - & - & - & - \\
\hline White & + & + & - & - & + & + & + & + & + & + \\
\hline White to olive buff & - & - & - & + & - & - & - & - & - & - \\
\hline Yellowish green & - & - & - & - & - & - & - & - & - & + \\
\hline Production of soluble pigment & + & - & + & + & + & - & - & - & - & - \\
\hline \multicolumn{11}{|l|}{ Acid production from: } \\
\hline Adonitol & + & + & + & - & - & + & - & + & + & - \\
\hline $\mathrm{L}(+)$ Arabinose & + & + & + & - & $w$ & + & + & - & + & - \\
\hline $\mathrm{D}(+)$ Cellobiose & + & + & + & + & + & + & + & + & + & - \\
\hline Dextrin & - & + & + & + & $\mathrm{w}$ & + & + & - & + & + \\
\hline meso-Erythritol & + & + & + & - & - & + & - & + & + & - \\
\hline $\mathrm{D}(+)$ Fructose & + & + & + & + & $w$ & + & + & + & + & + \\
\hline $\mathrm{D}(+)$ Galactose & + & + & + & + & w & + & + & + & + & + \\
\hline meso-Inositol & - & + & + & + & - & + & + & - & + & - \\
\hline $\mathrm{D}(+)$ Lactose & + & + & + & - & - & + & + & - & + & - \\
\hline $\mathrm{D}(+)$ Maltose & - & + & + & + & $\mathrm{w}$ & + & + & - & + & + \\
\hline $\mathrm{D}(-)$ Mannitol & + & + & + & + & - & + & + & + & + & + \\
\hline $\mathrm{D}(+)$ Melezitose & - & - & - & - & - & - & - & - & - & - \\
\hline $\mathrm{D}(+)$ Melibiose & + & + & + & - & - & + & + & - & - & - \\
\hline Methyl $\alpha$-D-glucoside & + & + & + & + & w & + & - & - & + & - \\
\hline $\mathrm{D}(+)$ Raffinose & + & + & + & - & $\mathrm{w}$ & + & + & - & + & - \\
\hline L(+)Rhamnose & - & - & - & - & - & - & + & + & + & - \\
\hline Salicin & + & + & + & + & - & + & + & $w$ & + & - \\
\hline $\mathrm{D}(-)$ Sorbitol & + & - & - & - & - & - & $\mathrm{w}$ & + & - & - \\
\hline Sucrose & - & + & + & + & $\mathrm{w}$ & + & + & + & + & + \\
\hline $\mathrm{D}(+)$ Trehalose & + & w & + & + & $\mathrm{w}$ & + & + & + & + & + \\
\hline $\mathrm{D}(+)$ Xylose & + & + & + & + & - & + & + & + & + & - \\
\hline \multicolumn{11}{|l|}{ Decomposition of: } \\
\hline Allantoin & + & + & - & - & - & + & - & + & - & - \\
\hline Casein & + & + & + & + & + & + & + & - & + & - \\
\hline Aesculin & + & + & + & + & - & + & + & $\mathrm{w}$ & + & - \\
\hline Gelatin & - & + & + & + & - & + & + & + & + & + \\
\hline Hypoxanthine & + & + & + & + & - & + & + & + & + & - \\
\hline Xanthine & + & + & + & - & - & + & - & + & - & - \\
\hline \multicolumn{11}{|l|}{ Growth at: } \\
\hline $10^{\circ} \mathrm{C}$ & - & - & + & + & + & + & + & - & + & - \\
\hline $45^{\circ} \mathrm{C}$ & + & - & - & - & + & - & - & + & + & - \\
\hline Growth in presence of $5 \% \mathrm{NaCl}(\mathrm{w} / \mathrm{v})$ & + & - & + & + & - & w & $\mathrm{w}$ & + & $\mathrm{w}$ & - \\
\hline
\end{tabular}

the resulting trees were evaluated by bootstrap analyses (Felsenstein, 1985) of the neighbour-joining method based on 1000 resamplings. All of the phylogenetic analyses were carried out using the PHYLIP package (Felsenstein, 1993).

DNA-DNA relatedness studies. Levels of genomic relatedness between strain $\mathrm{N} 1165^{\mathrm{T}}$ and $A$. methanolica IFO $15065^{\mathrm{T}}$ were determined by using a DNA-DNA slot blot hybridization method (Kafatos et al., 1979), as described by Chun et al. (1998).

\section{RESULTS AND DISCUSSION}

Almost complete 16S rDNA sequences were obtained for strain $\mathrm{N} 1165^{\mathrm{T}}$ (1495 $\mathrm{nt}$ ) and for the type strains of A. alba, A. coloradensis and $A$. sulphurea. Phylogenetic comparison of the sequence of strain $\mathrm{N} 1165^{\mathrm{T}}$ with corresponding nucleotide sequences of representatives of the family Pseudonocardiaceae show that the organism belongs to the genus Amycolatopsis (Fig. 1). It 
is also clear from the phylogenetic trees that the strain forms a monophyletic clade with $A$. methanolica. This relationship is supported by the $100 \%$ bootstrap value recorded using the neighbour-joining method. The $16 \mathrm{~S}$ rDNA sequence similarity between strain $\mathrm{N} 1165^{\mathrm{T}}$ and the type strain of $A$. methanolica is $98.8 \%$; this value corresponds to 16 differences out of $1328 \mathrm{nt}$ positions compared. Similarity values with the type strains of the remaining validly described Amycolatopsis species range from 93.8 to $94.4 \%$.

The assignment of the test strain to the genus Amycolatopsis is also supported by the biochemical, chemotaxonomic, morphological and physiological data. The organism is aerobic, non-motile, Grampositive, non-acid-alcohol-fast and forms a substrate mycelium which fragments into squarish elements. Strain $\mathrm{N}_{1165^{\mathrm{T}}}$ contains meso- $\mathrm{A}_{2} \mathrm{pm}$ as the wall diamino acid, arabinose and galactose as major sugars, predominant amounts of tetrahydrogenated menaquinone with nine isoprene units and DNA with a $\mathrm{G}+\mathrm{C}$ content of $75 \mathrm{~mol} \%$. The organism also contains major proportions of 14-methylpentadecanoic acid $(29 \%$ of total cellular fatty acid composition), $\alpha$-hydroxy-14-methylpentadecanoic acid $(16 \%)$ and 14-methylhexadecanoic acid (14\%) with smaller proportions of 13-methyltetradecanoic acid $(4 \%)$, 15-methylhexadecanoic acid $(5 \%)$, hexadecanoic acid $(8 \%)$, hexadecenoic acid $(6 \%)$, 14methylpentadecenoic acid (5\%), 2-hydroxy-16methylheptadecanoic acid $(5 \%)$ and octadecenoic acid $(4 \%)$, but it lacks mycolic acids. These properties are consistent with the classification of the strain in the genus Amycolatopsis (Holt et al., 1994).

Strain $\mathrm{N} 1165^{\mathrm{T}}$ can be distinguished from representatives of all validly described species of Amycolatopsis, including $A$. methanolica, using a combination of phenotypic properties (Table 1). It is also clear from DNA-DNA relatedness data that the test strain and $A$. methanolica IFO $15065^{\mathrm{T}}$ belong to different genomic species. The two strains showed a DNA relatedness value of $21 \%$ under optimal conditions when DNA from the $A$. methanolica strain was used as the probe. When DNA from strain N1165 was labelled, the relatedness value fell to $5 \%$. It is evident from these genotypic and phenotypic data that strain $\mathrm{N} 1165^{\mathrm{T}}$ merits species status in the genus Amycolatopsis. It is proposed that the organism be classified in the genus Amycolatopsis as Amycolatopsis thermoflava sp. nov.

\section{Description of Amycolatopsis thermoflava sp. nov.}

Amycolatopsis thermoflava (ther.mo.fla.va. Gr. $\mathrm{n}$. therme heat; L. adj. flavus yellow; M.L. adj. thermoflava thermophilic, yellow).

The description is based on data taken from this and an earlier study (Lu \& Yan, 1983). Aerobic, Grampositive, non-acid-alcohol-fast, non-motile actinomycete which forms an extensively branched substrate mycelium which fragments into squarish elements $(0.6-0.7 \times 6.5-14.0 \mu \mathrm{m})$. The aerial mycelium is sterile, sparse and white, and the substrate mycelium is yellow. A yellowish diffusible pigment is produced. Produces nitrate reductase, phosphatase and urease, but not amylase. The organism, which grows between 28 and $55^{\circ} \mathrm{C}$, but not at 10 or $60^{\circ} \mathrm{C}$, is resistant to lysozyme and penicillin. Other phenotypic properties are given in Table 1 . The $\mathrm{G}+\mathrm{C}$ content of the DNA is $75 \mathrm{~mol} \%$ ( $T_{\mathrm{m}}$ method). Isolated from a soil sample collected in Hainan Island, China. The type strain is $\mathrm{N} 1165^{\mathrm{T}}$ (= IFO $14333^{\mathrm{T}}$ ). The species description is based on a single strain and hence serves as the type strain description.

\section{ACKNOWLEDGEMENTS}

Part of this work was supported by the UK-Korea Actinomycete Research Programme (BBSRC grant R185/ 05688/01), the British Council Academic Link Scheme and KOSEF grant 966-0502-002-2 to SRC (Research Center for Molecular Microbiology). S. B. K. is grateful for support from a Chevening-MOST scholarship. The authors are also indebted to R. M. Kroppenstedt for providing some of the cultures and to Sunny C. Jiang for translating the original paper on 'Nocardia thermoflava' from the Chinese.

\section{REFERENCES}

Chun, J. \& Goodfellow, M. (1995). A phylogenetic analysis of the genus Nocardia with 16S rRNA gene sequences. Int $J$ Syst Bacteriol 45, 240-245.

Chun, J., Blackall, L. L., Kang, S.-O., Hah, Y. C. \& Goodfellow, M. (1997). A proposal to reclassify Nocardia pinensis Blackall et al. as Skermania piniformis gen. nov., comb. nov. Int $J$ Syst Bacteriol 47, 127-131.

Chun, J., Seong, C.-N., Bae, K. S., Lee, K.-J., Kang, S.-O., Goodfellow, M. \& Hah, Y. C. (1998). Nocardia flavorosea sp. nov. Int J Syst Bacteriol 48, 901-905.

Embley, T. M., Smida, J. \& Stackebrandt, E. (1988). The phylogeny of mycolate-less wall chemotype IV actinomycetes and description of Pseudonocardiaceae fam. nov. Syst Appl Microbiol 11, 44-52.

Felsenstein, J. (1985). Confidence limits on phylogenies: an approach using the bootstrap. Evolution 39, 783-791.

Felsenstein, J. (1993). PHYLIP (phylogenetic inference package) version 3.5c. Department of Genetics, University of Washington, Seattle, WA, USA.

Fitch, W. M. (1972). Toward defining the course of evolution: minimum change for a specific tree topology. Syst Zool 20, 406-416.

Fitch, W. M. \& Margoliash, E. (1967). Construction of phylogenetic trees: a method based on mutation distances as estimated from cytochrome $c$ sequences is of general applicability. Science 155, 279-284.

Goodfellow, M., Brown, A., Cia, J., Chun, J. \& Collins, M. D. (1997). Amycolatopsis japonicum sp. nov., an actinomycete producing (S,S)-N, $\mathrm{N}^{\prime}$-ethylenediaminedisuccinic acid. Syst Appl Microbiol 20, 78-84.

Gordon, R. E. \& Mihm, J. M. (1962). Identification of Nocardia caviae nov. comb. Ann N Y Acad Sci 98, 628-636.

Gordon, R. E., Barnett, D. A., Handerhan, J. E. \& Pang, C. H. N. 
(1974). Nocardia coeliaca, Nocardia autotrophica, and the nocardin strain. Int J Syst Bacteriol 24, 54-63.

Holt, J. G., Krieg, N. R., Sneath, P. H. A., Staley, J. T. \& Williams, S. T. (1994). Bergey's Manual of Determinative Bacteriology, 9th edn. Baltimore: Williams \& Wilkins.

Jukes, T.H. \& Cantor, C.R. (1969). Evolution of protein molecules. In Mammalian Protein Metabolism, vol. 3, pp. 21-132. Edited by H. N. Munro. New York: Academic Press.

Kafatos, F. C., Jones, C. W. \& Efsratiadis, A. (1979). Determination of nucleic acid sequence homologies and relative concentrations by a dot hybridization procedure. Nucleic Acids Res 7, 1541-1545.

Kim, S. B. \& Goodfellow, M. (1999). Reclassification of Amycolatopsis rugosa Lechevalier et al. 1986 as Prauserella rugosa gen. nov., comb. nov. Int J Syst Bacteriol 49, 507-512.

Lechevalier, M. P. \& Lechevalier, H. A. (1970). Chemical composition as a criterion in the classification of aerobic actinomycetes. Int J Syst Bacteriol 20, 435-443.

Lechevalier, M. P., Prauser, H., Labeda, D. P. \& Ruan, J. S. (1986). Two new genera of nocardioform actinomycetes: Amycolata gen. nov. and Amycolatopsis gen. nov. Int J Syst Bacteriol 36, $29-37$.

Lu, Y. \& Yan, X. (1983). Studies on the classification of thermophilic actinomycetes IV. Determination of thermophilic members of Nocardiaceae. Acta Microbiol Sin 23, 220-228.

Mandel, M. \& Marmur, J. (1968). Use of ultraviolet absorbance temperature profile for determining the guanine plus cytosine content of DNA. Methods Enzymol 12B, 195-206.

Minnikin, D. E., Hutchinson, I. G., Caldicott, A. B. \& Goodfellow, M. (1980). Thin-layer chromatography of methanolysates of mycolic acid-containing bacteria. J Chromatogr 188, 221-233.
Minnikin, D. E., O'Donnell, A. G., Goodfellow, M., Alderson, G., Athalye, M., Schaal, A. \& Parlett, J. H. (1984). An integrated procedure for the extraction of isoprenoid quinones and polar lipids. J Microbiol Methods 2, 233-241.

Mordarska, H., Mordarski, M. \& Goodfellow, M. (1972). Chemotaxonomic characters and classification of some nocardioform bacteria. J Gen Microbiol 71, 77-86.

Saitou, N. \& Nei, M. (1987). The neighbor-joining method: a new method for constructing phylogenetic trees. Mol Biol Evol 4, 406-425.

Sasser, M. (1980). Identification of bacteria by gas chromatography of cellular fatty acids. Technical Note 101. Newark, DE: MIDI.

Skerman, V. B. D., McGowan, V. \& Sneath, P. H. A. (1980). Approved lists of bacterial names. Int $J$ Syst Bacteriol 30, 225-420.

Staneck, J. L. \& Roberts, G. D. (1974). Simplified approach to identification of aerobic actinomycetes by thin-layer chromatography. Appl Microbiol 28, 226-231.

Warwick, S., Bowen, T., McVeigh, H. \& Embley, T. M. (1994). A phylogenetic analysis of the family Pseudonocardiaceae and the genera Actinokineospora and Saccharothrix with 16S rRNA sequences and a proposal to combine the genera Amycolata and Pseudonocardia in the emended genus Pseudonocardia. Int $J$ Syst Bacteriol 44, 293-299.

Williams, S. T., Goodfellow, M., Alderson, G., Wellington, E. M. H., Sneath, P. H. A. \& Sackin, M. J. (1983). Numerical classification of Streptomyces and related genera. $J$ Gen Microbiol 129, 1743-1813.

Williams, S. T., Sharpe, M. E. \& Holt, J. G. (1989). Bergey's Manual of Systematic Bacteriology, vol. 4. Baltimore: Williams \& Wilkins. 